\title{
Organizational and Pedagogical Conditions Development of General Competences Formation in the Educational Activities of the University
}

\author{
Irina V. Rudenko ${ }^{1}$, Nailya I. Fedorova ${ }^{2}$, Isita V. Muskhanova ${ }^{3}$, Satzita A. Alieva ${ }^{3}$, Banati C.-A. Kasumova ${ }^{3}$, Zarina I. \\ Gadaborsheva $^{3}$, Elena V. Gunina ${ }^{4} \&$ Konstantin B. Tumarov ${ }^{5}$ \\ ${ }^{1}$ Togliatti State University, Togliatti, Russia \\ ${ }^{2}$ Kazan (Volga region) Federal University, Kazan, Russia \\ ${ }^{3}$ Chechen State Pedagogical Institute, Grozny, Russia \\ ${ }^{4}$ Chuvash State Pedagogical University named after I.Y. Yakovlev, Cheboksary, Russia \\ ${ }^{5}$ Naberezhnye Chelny branch of Kazan National Research Technical University named after A. N. Tupolev - \\ KAI (KNRTU-KAI), Naberezhnye Chelny, Russia \\ Correspondence: Irina V. Rudenko, Togliatti State University, 445667, Togliatti, Belorusskaya Street, 14, Russia. \\ E-mail: solo73@inbox.ru
}

Received: June 13, 2015 Accepted: June 21, 2015 Online Published: June 29, 2015

doi:10.5539/jsd.v8n6p45 URL: http://dx.doi.org/10.5539/jsd.v8n6p45

\begin{abstract}
The urgency of this problem is justified by the fact that not only training, but also educational activities of the University should be directed to the development of future professional's personality, on the formation of his or her professional and cultural competences. In this regard, this article contains a study how to form bachelors of Humanities' professional competencies in higher education. The basis of the study of this problem are the ideas of competence-based approach, the theory of the individual's entity, allowing on the basis of educational organizations' activity improvement to solve the problem of the graduate's personality professional formation. The article demonstrates the capabilities of the universities' educational activities in situations of pedagogical interaction between teachers and students to prepare future professionals, reveals the role of the teacher supervisor of the student groups. Organizational and pedagogical conditions of bachelors' professional competencies' formation in the course of educational activities and the results of their testing during the pedagogical experiment are developed in the article. This article is intended for teachers, researchers, heads of educational institutions who are engaged in education and training at the University.
\end{abstract}

Keywords: higher education, competence approach, personality's entity, professional competence, education entities

\section{Introduction}

\subsection{Background}

The problem of higher education institutes' students' professional competence formation exists in connection with the adopted in most European countries General concept of higher education educational standard and the transition in bachelors, masters' training to the competence approach. The essence of competence-based approach, which is highlighted by domestic researchers (Bolotov \& Serikov, 2003; Baydenko, 2006; Ivanov et al., 015) is concerned with understanding of the universities' training process as a system that integrates academic and extra-curricular activities, and they are both focused on the students' mastering of ways of activities, generalized skills which are presented in high school standard as strategic categories: general cultural, general professional, professional competences. The specific potential of education, the priority of which is recorded in public documents is evidently underestimated at the present stage of the vocational education's theory and practice. The competence-based approach's development to the professional education's process study the results of which will be graduates' competencies will contribute to educational organizations' activity improvement, will allow justify innovative role of the educational organization (higher and secondary education) as important cycles of developing system of continuous education. 


\subsection{Status of a Problem}

Humanistic philosophic and psychological theories (Maslou, 2001) had an impact on the new pedagogical paradigm's justification, a new perspective on the student as the education's entity. Humanistic paradigm suggests that the trained student should be recognized as the main value of educational process of the University. The role of the students in their own development becomes a priority. In this connection it is essential to find mechanisms and ways of the educational process organizing in the institution in which the whole system of university education is determined by the strategic objective of graduates' personality professional formation. This fact confirms the necessity of the educational institutions' educational environment optimization, which would have created organizational-pedagogical conditions for students' professional and personal development and formed the required competencies. The high level of their formation will provide in the future, the ability to realize certain values and life meanings in their professional sphere, that is, the characteristics of an educational result.

\subsection{The Research Hypothesis}

In the phrase "organizational and pedagogical conditions" concepts are combined, the meaning of which is necessary to provide through each category's understanding separately. Usually, there are two groups of conditions: the necessary ones, which contribute to the system's emergence and development, and the sufficient ones, which are generated by combining into a system of individual items, groups of items or the whole plurality. On the basis of common positions, we focus on the following sufficient conditions which are typical for any organization, regardless of the direction of bachelors' training . In researchers' scientific experience (Galkina, 2009; Lapteva, 2001; Pavlov, 1999 and others) we find attempts to define the concept of "organizational-pedagogical" conditions such as: organizational resources and activities; a set of interrelated assumptions, providing targeted management by the process (material, human, information); provision of three levels of organization's management (institutional, managerial, technical). In our opinion, this concept requires the activity entity's identification, which will carry out organizational changes; understanding of its regulatory actions leading to the process adjustment; and the activities' methods' implementation, directed on pedagogical result achievement.

\section{Materials and Methods}

\subsection{Research Objectives}

We have identified the following research objectives:1) to substantiate and develop the organizational-pedagogical conditions of professional competences' formation in university educational activities; 2) to introduce these conditions into the university educational process; 3 ) to check the effectiveness of the developed conditions in the professional training of University students.

\subsection{Theoretical and Empirical Methods}

Organizational-pedagogical conditions' development involves the use of a number of approaches, among which there are system, activity and personal one. The system approach allows consider the educational process as a system and in accordance with its structural components to determine the conditions which are necessary and sufficient for general competences' formation in the educational environment of the University. From the standpoint of humanistic psychology (A. Maslow, K. Rogers) it is indispensable for the effective education to use an activity-based approach, which means to rely on internal force of personality, "the inner logic of his or her development" (Leontev, 1977). Therefore, from the point of view of the activity approach a joint activity of educational process's entities on the goals', content's, adequate forms' and methods' of professional development selection lies in the educational foundations. The learner-centered approach is a fundamental one in the development of organizational-pedagogical conditions. While it's choosing, we should pay attention to the point by N. M. Boryitko, N. K. Sergeeva that "the through idea of modern education is the formation of students' orientation on continuous professional and personal self-improvement, transformation of themselves for tasks' solving of complex creative professional activity" (Sergeev \& Borytko, 2003).

The appeal to this approach is determined by a complex of factors:

- level of students' general, primary and secondary vocational education;

- "stage of learning in the University" (first course, graduate, undergraduate);

- individual experiences (work, life, social);

- individual characteristics (psychological, physical, communicative, etc.);

- traditions in extracurricular activities of the University. 
All of these approaches were taken into consideration in the process of experimental work.

\subsection{Research Methodological Principles}

The analysis of the Federal state standard of higher education, instructional guidelines of educational-methodical offices in different areas allowed us to identify three fundamental principles that are the basis for the educational activities of the University and its educational components: consistency, student-centered, continuity.

The principle of consistency means the compliance of content, methods, forms, means, technologies and mechanisms for results' evaluation to the objectives of the educational process (Stepanov \& Luzin, 2002; Levina et al., 2015). In addition, this principle implies the relationship and interdependence of functional components (training, education, self-development) in educational outcomes' achieving (Telegina et al., 2015). That is why the design of the Basic educational program for all areas of training cannot be carried out only with reference to the learning process.

The student-centered principle means a reorientation of the educational process on personal results. Training and educational process focused on the student, is largely determined by what do students want to achieve and how they meet the requirements to graduate of a specific profession. These correspondences in the current environment are determined as the categories of "competence".

Continuity means the phased development of the entity and cognitive position of students; the relationship between the various phases and stages of study at the University, which is manifested in the coordination of educational tasks, the allocation for each course of cross-cutting competencies; keeping the unity of the pedagogical requirements (Rudenko, 2012).

\subsection{The Basis of the Research}

The experimental work was conducted in the period from 2009 till 2014 on the Samara state technical University territory and in Togliatti state University.

\section{Results}

As assumptions the following conditions were developed:

- educational activities' framework development in educational organizations;

- students' positive motivation support to participate in social significant activities;

- students' involvement in innovative projects of the University;

- social partnership with various organizations which do not belong to the system of higher education;

- humanistic position of the teacher, who is able through interaction active methods' using to provide guidance for students on self-development, self-education.

The first pedagogical condition is associated with tasks' solving of three levels: strategic, conceptual and tactical (Rudenko, 2013). Strategic level means the allocation of basic values in educational activities, appropriate to social request. Federal state standards based on the competence approach, provide an opportunity to clarify the objectives of education and to transform them into the measured form - of competencies as outcomes of professional education. On the other hand, the University needs a creation of a socio-cultural environment supporting the full development of the individual student.

Conceptual level manifests itself as a conceptualization of education, a developed concept, application or other document approved by the academic Council of educational organization that develops taking into account specific vocational training, economic, regional, national characteristics, development's history and traditions of the main directions of educational activity.

Organizational level provides the link between all the entities of educational activity, determines the forms and methods of educational work at all levels, the management of this process.

The formation of a competence model of a graduate gives to the developers of the basic educational curriculum the objective of relations' establishing between competences and disciplines. It would be wrong if educational work and its important component - extracurricular activities - would be dropped out of the professional context. That is why during the development of the basic educational curriculum in Togliatti State University there was an attempt to integrate academic and extra-curricular activities in the matrix of competencies, as well as in the description of educational technologies used in educational process.

The second condition is a support in students' positive motivation to participate in socially important activity in order to contribute to the youth creative potential's revival, capable of a productive professional activity. It is the 
participation in socially significant activities will facilitate the mastering of new skills. The students' motivation to participate in these activities is also achieved through moral and material incentives' using. Motivation to participate in socially important activities is a part of the professional motivation which is the internal driving factor of student's position development, because only on the basis of its formation can be facilitated effective development of students' professional competence.

The third pedagogical condition is the involvement of students in innovative projects of the University, which contributes to the advancement of students in their professional development. In order to implement this condition successfully, it is necessary to include students in projects which have personal significance for them. The entity role of the student in the activities of the group is represented by a complex of social roles, positions that carry a certain social and educational impact on the individual: responsible, executive member of the group; the initiator of ideas, practical affairs; the organizer of a particular activity; an elected group leader, the leader recognized by the members of the group for some positive things, human qualities, and others (Aliyeva, 2012). And each of these roles can be implemented in the educational environment of the educational organization. The implementation of these roles will be to encourage students to professional and personal improvement, based on the fact that extra-curricular work, providing opportunities for self-realization, ensures the development of their entity.

The next condition - social partnership with various organizations which do not belong to the system of higher education - involves cooperation with employers and potential "customers" of specialists of this profile. Cooperation with bodies not belonging to the system of higher education, allows students to gain practical experience in the process of participation in social projects. Specifics of these conditions is that its implementation contributes to the development of the ability to establish and develop business relations with representatives of various commercial, non-profit and other organizations, therefore, has an impact on one of the most important competencies which means students' ability to install, maintain and develop business relationships with third party organizations.

One of the significant problems that can be solved when implementing this condition - is a case when each student is assisted in gaining autonomy in organized activities. In line with this, the named condition will contribute to the development of skills to take responsibility for decisions' making, to make decisions in unusual situations, to support the pursuit of self-development and self-education, which is the content of professional competence of students of psychological and pedagogical education.

Condition's implementation - humanist position of teacher who is able through the use of active methods of interaction to provide guidance of students on self-development, self-education, reveals the mission of the teacher as the entity of the educational process at the University. The activity of the teacher is primarily associated with the educational process. Taking into account that in the process of higher education under the influence of training students' values' are changed, the teacher should not only be a transmitter of knowledge, but also the translator of universal values. Today the teacher of the University in extra-curricular activities: student' adviser of the student group, the coordinator of student associations, the developer (together with the students) of innovative projects and curricula; tutor - mentor of students in their individual professional and personal self-determination, psychologist, lawyer-consultant, art Director of associations, studios, master, trainer, organizer of important events in the University, in the country, Manager; member and participant of the creative pedagogical communities, etc. If the purpose of the teacher acts as an internal guide of personal and professional development, then we are dealing with a humanistic teacher's position (Nefedova, 2008).

Currently we have urgent problem of the students' adviser's activities of the student group, his or her role in the system of professional education. Surveys and interviews of students of Samara state technical University (245 people), Volga region state social-humanitarian Academy (El.), Togliatti state University (CA.) confirmed that students' adviser of the student group is one of the most significant figures in extracurricular system of the University; it is the interaction with him or her is important for students who are waiting for help in the adaptation to University (98\%), establishment of a favorable psychological climate in the group (66\%), the preparation of individual professional improvement program (82\%), and others.

\subsection{The Results of Experimental Work on the Organizational-Pedagogical Conditions'Implementation}

Let's see the results of implementation of these terms in the activities of the students' adviser in student group of Beylina N.C.(candidate of pedagogical Sciences, the winner of the contest "the Best students' adviser of the year 2014" in the Samara state technical University) under the guidance of Ph. D. Rudenko, I. V. (Rudenko, 2013).

To implement these terms in the activities of the teacher as students' adviser of the group on the formation of students' professional competences of the specialty "Advertising and public relations" the main stages of work 
were designed.

The first phase-adaptive cognitive (year 1) - focused on the adaptation of students in the University and providing them with a theoretical propaedeutic block of information on social psychology, conflictology, valeology. Previously the students' adviser conducts an analysis of the FSES (federal state educational standards), the Basic educational curriculum in the areas of training, studying curriculum, performing analysis of skills, general cultural and professional competences, conducts adaptation of extracurricular activities' curricula under the requirements of the standard. Due to the fact that special classes are in the schedule, his or her activity at this stage, the students' adviser of the student group implements in the framework of the authors' curriculum of curatorial hours "me and my profession". The purpose of this curriculum is students' general and cultural professional competence forming.

The second stage of the project activity (year 2) - aims at students' involvement in the project activities. The choice of project activities as a continuation of work on professional competences' formation, which started in the first course is not accidental: first, the project activity contributes to the strengthening of the skills of team work, teaches to argue and make their own decisions, to maintain a favorable psychological climate in the team. The project activity promotes personalities' self-realization, satisfaction of interests and needs. Students' adviser actively carries out Advisory activities, providing students mastering the basics of project activities, helps to engage in projects in accordance with the interests and capabilities.

In the third stage (3rd year) - practice-transforming one -activities are undertaken directed for independent work of students. At this stage, in the framework of Supervisory hours situations, which are close to professional are created. Future specialists are encouraged to independently develop and implement projects related to their professional field. The process of implementation of the considered stage is performed in the student laboratory "Creativity and intelligence". For the successful student activities' implementation the students' advisor uses mass media, huge businesses companies and other organizations. The students' adviser at this stage assists the student in obtaining of social and professional experience, as well as creates conditions for the realization of scientific and creative potential of students.

The position of the teacher-supervisor has the nature of organic interaction with students, and is a model of democratic relations, common interests, the results of joint activities. An important component of the students' advisor's activities are forms and methods of work. Based on the classification of N. M. Borytko (2005), these methods can be systematized as follows: reflexive (method of dramatization, writing-essays, persuasion, suggestion, method of example), value (method of stimulation; requirement, dialogue), projective (method of exercise, method of social samples, competition), complex (the method of bringing up situations; counseling).This classification in the study of N. S. Beylina is supplemented by active methods, which can be attributed to projective and reflective: a case study, role play, debate, conversation, brainstorming (Beylina, 2013).

These methods allow students to develop the positive attitude of students to their future professional activities, to realize themselves and to assert themselves in social and professional space. An important feature of these methods is that they are based on active approach. Project method used in the work, stimulates intellectual, emotional, and other personal sphere of the student, which affects the personal development of the future professional. Knowledge of the basics of design culture and gain of practical experience in the development and implementation of social projects will contribute to raising the level of motivation for self-learning and self-realization. The data obtained allowed to establish that the activity of the students' adviser has influenced the formation of basic knowledge in the General area of foundations of psychology and ethics of business communication, conflict resolution, valeology, fundamentals of project activities, ability to work in a team, to make decisions in unusual or crisis situations, to collaborate with colleagues in solving common problems, that is the essence of the competencies outlined in the standard for this line of training.

\section{Discussions}

Summarizing, we can conclude that educational activities in the University will contribute to the achievement of learning outcome - the formation of competencies - if it is purposefully organized. On the example of activity of one of the entities in the educational work - the students' advisor of the student group in the process of learning and reflection of the positive experience, the essence of organizational-pedagogical conditions in realization of the specific potential of education in the modernization of the educational activities at the University is revealed. The theoretical and empirical data allowed us to draw conclusions about the importance of education in the training of modern professionals.

\section{Conclusions}

The status of education as a socially valuable spiritual and practical activity at the University specifies the need 
to identify and correlate the results of this activity at the stages of professional education with the requirements of the Federal educational standard of the higher school. Consequently, education in the University should be considered in a professional context, and the results with the professional competencies' formation.

\section{Acknowledgments}

The authors thank all participants of this study for their kind cooperation.

\section{References}

Aliyeva, L. V. (2012). Extracurricular activities of the university - the base of formation of personal and professional positions polysubject teacher-tutor. Teacher Education in CIS countries: current issues, concepts, theories and practice. St. Petersburg, FGNU IPOOV waste: 63-68.

Baydenko, V. I. (2006). Identify staff competencies of graduates as a necessary stage of designing a new generation SES of HPE: method. Moscow publisher Research center of problems of quality of training, 54.

Beylina, N. S. (2013). Formation of social competence of students by means of curatorial activities. The journal Perspectives of Science and Education, 2, 61, 64.

Bolotov, V. A., \& Serikov, V. V. (2003). Competence model: from the idea to the educational paradigm. The journal Pedagogy, 10, 8-14.

Borytko, N. M. (2005). The system of vocational education in high school. Moscow publisher, 120.

Galkina, O. V. (2009). The role and place of the concept of "organizational and pedagogical conditions in the terminological apparatus of pedagogy", Samara, 23.

Ivanov, V. G., Shaidullina, A. R., Drovnikov, A. S., Yakovlev, S. A., \& Masalimova, A. R. (2015). Regional Experience of Students' Innovative and Entrepreneurial Competence Forming. Asian Social Science, 11(1), $35-40$.

Lapteva, L. B. (2001). Organizational-pedagogical conditions of realization of the tasks of school. St. Petersburg, publisher state pedagogical University them. AI Herzen, 22.

Leontev, A. N. (1977). Activities. Consciousness. Personality. Moscow publisher Politizdat, 304.

Levina, E. Y., Akhmetov L. G., Latipova L. N., Mirzagitova A. L., Mirzanagimova F. I., Latipov Z. A., \& Masalimova A. R. (2015). Diagnostics of Educational Activity Quality on the Basis of Qualitative Methods. Asian Social Science, 11(4), 246-251.

Maslou, A. (2001). Motivation and Personality St. Petersburg publisher Eurasia, 478.

Nefedova, N. A. (2008).Theoretical and practical aspects of the education of students of higher educational institutions: training programs and guidelines. Moscow Publishing House. "MNEPU", 128.

Pavlov, S. N. (1999). Organizational-pedagogical conditions of formation of public opinion by local. Magnitogorsk publisher Magnitogor. state. ped. Inst, 23.

Rudenko, I. V. (2012). Education in the context of professional. Vector Science, 1, 280-282.

Rudenko, I. V., \& Beilin, N. S. (2013). Activities curator student group as an innovative block extracurricular activities in high school. Togliatti State University, Vector Science, 4, 280-282.

Sergeev, N. K., \& Borytko, N. M. (2003). Becoming subjectivity specialist in educational space of continuing professional education. Pedagogical problems of subjectivity formation schoolchildren, students in continuing education. Volgograd. 5-9.

Stepanov, E. N., \& Luzin, L. M. (2002). The teacher of modern approaches and concepts of education. Moscow publisher Creative Center, 160.

Telegina, N. V., Galimova, E. G., \& Masalimova, A. R. (2015). The Structure and Content of the Model of Pedagogical Conditions Binary Approach to Optimization of Control and Diagnostic Functions in Teaching "General pedagogy" to Students. Asian Social Science, 11(1), 364-368.

\section{Copyrights}

Copyright for this article is retained by the author(s), with first publication rights granted to the journal.

This is an open-access article distributed under the terms and conditions of the Creative Commons Attribution license (http://creativecommons.org/licenses/by/3.0/). 